\title{
Atmospheric column-averaged mole fractions of carbon dioxide at 53 aircraft measurement sites
}

\author{
Y. Miyamoto ${ }^{1, *}$, M. Inoue ${ }^{1}$, I. Morino ${ }^{1}$, O. Uchino ${ }^{1}$, T. Yokota ${ }^{1}$, T. Machida ${ }^{1}$, Y. Sawa ${ }^{2}$, H. Matsueda ${ }^{2}$, C. Sweeney ${ }^{3}$, \\ P. P. Tans ${ }^{3}$, A. E. Andrews ${ }^{3}$, and P. K. Patra ${ }^{4}$ \\ ${ }^{1}$ National Institute for Environmental Studies (NIES), Tsukuba, Japan \\ ${ }^{2}$ Meteorological Research Institute (MRI), Tsukuba, Japan \\ ${ }^{3}$ National Oceanic and Atmospheric Administration (NOAA), Boulder, Colorado, USA \\ ${ }^{4}$ Japan Agency for Marine-Earth Science and Technology (JAMSTEC), Yokohama, Japan \\ * now at: Graduate School of Natural Science and Technology, Okayama University, Okayama, Japan
}

Correspondence to: I. Morino (morino@nies.go.jp)

Received: 4 October 2012 - Published in Atmos. Chem. Phys. Discuss.: 30 October 2012

Revised: 24 April 2013 - Accepted: 25 April 2013 - Published: 27 May 2013

\begin{abstract}
Atmospheric column-averaged mole fractions of carbon dioxide $\left(\mathrm{XCO}_{2}\right)$ at 53 locations around the world were derived from aircraft measurements covering the altitude range of about $1-10 \mathrm{~km}$. We used $\mathrm{CO}_{2}$ vertical profile measurements from three major carbon cycle programs, a global climatological data set of air number density profiles and tropopause height for calculating $\mathrm{XCO}_{2}$ for the period of 2007-2009. Vertical profiles of the $\mathrm{CO}_{2}$ mixing ratio are complemented by tall tower data up to $400 \mathrm{~m}$ from the earth's surface and by simulated profiles in the stratosphere from a chemistry-transport model. The amplitude of the seasonal cycle of calculated $\mathrm{XCO}_{2}$ values shows clear latitudinal dependence, and the amplitude decreases from about $10 \mathrm{ppm}$ at high latitudes in the Northern Hemisphere to at most 2 ppm in the tropics and the Southern Hemisphere. The uncertainties of $\mathrm{XCO}_{2}$ were estimated from assumptions about $\mathrm{CO}_{2}$ profiles for each flight. Typically, uncertainties were less than $1 \mathrm{ppm}$; thus, this data set is within the level of uncertainty needed for primary validation of $\mathrm{XCO}_{2}$ measurements by the Greenhouse gases Observing SATellite (GOSAT) and by future satellite missions for monitoring greenhouse gases.
\end{abstract}

\section{Introduction}

Atmospheric abundance of $\mathrm{CO}_{2}$ has drawn great interest in the recent decade because $\mathrm{CO}_{2}$ is the most important anthropogenically produced greenhouse gas (WMO, 2006). The
Greenhouse gases Observing SATellite (GOSAT), launched on 23 January 2009, is equipped with a Fourier transform spectrometer (FTS) to observe the atmospheric columnaveraged mole fraction of $\mathrm{CO}_{2}\left(\mathrm{XCO}_{2}\right)$ at more uniform geographical coverage than the in situ measurement network (WDCGG, 2012). GOSAT overpasses the region from $80^{\circ} \mathrm{S}$ to $80^{\circ} \mathrm{N}$ in longitudinal bands every 3 days. From 4 April 2009 to 31 July 2010, observational points were $\sim 158 \mathrm{~km}$ apart cross-track and $\sim 152 \mathrm{~km}$ apart along-track at the equator with the 5 point cross-track scan mode, and since 1 August 2010, observational points are $\sim 263 \mathrm{~km}$ apart cross-track and $\sim 283 \mathrm{~km}$ apart along-track at the equator with the 3 point cross-track scan mode (Yokota et al., 2009; Kuze et al., 2009; Yoshida et al., 2011). In contrast, the in situ measurement network is comprised of fewer than 216 sites (WDCGG, 2012). $\mathrm{XCO}_{2}$ measurements by remote sensing will provide another perspective for studying carbon cycle processes by better constraining the surface fluxes through inverse modeling. Modeling studies have shown that uncertainty of the source/sink inversion results is linked to the error of the satellite $\mathrm{CO}_{2}$ measurements (e.g., Rayner et al., 2002; Patra et al., 2003). Miller et al. (2007) showed that precisions of 1-2 ppm in $\mathrm{XCO}_{2}$ satellite measurements are needed to improve our knowledge of carbon cycle phenomena. Therefore, it is important to evaluate the quality of data obtained from satellites by comparing them with more accurate, though sparse, in situ observations. 
Because of their high accuracy, aircraft profile measurements are used for comparison with satellite data, but these measurements are limited in frequency and spatial density. Recently, the CONTRAIL (Comprehensive Observation Network for TRace gases by AIrLiner) project, by using commercial airplanes, has succeeded in measuring frequent and vertically dense data over a number of airports (Machida et al., 2008). $\mathrm{CO}_{2}$ mixing ratios recorded during takeoff and landing can be used to calculate $\mathrm{XCO}_{2}$ above airports.

Another $\mathrm{XCO}_{2}$ data set useful for validating satellite data is from the Total Carbon Column Observing Network (TCCON, Wunch et al., 2010, 2011a, b; Morino et al., 2011; Schneising et al., 2012), a ground-based FTS network. The measurement uncertainty of the FTS system, which has been certified by aircraft measurements, is similar to that of aircraft measurements, and this FTS network covers a wider area, but the number of aircraft measurements sites is greater than that of the TCCON sites.

Araki et al. (2010) reported $\mathrm{XCO}_{2}$ values calculated over Tsukuba, Japan, from CONTRAIL data obtained at Narita Airport and ancillary data sets. They also estimated the uncertainty derived from the assumptions made about the air density profile, the tropopause height, and the $\mathrm{CO}_{2}$ profile near the surface.

In this study, we report the results of $\mathrm{XCO}_{2}$ calculations carried out with data provided by CONTRAIL, measurements made by the US National Oceanic and Atmospheric Administration (NOAA) and Japan's National Institute for Environmental Studies (NIES) at 53 sites between 2007 and 2009. The method used in this study is similar to that of Araki et al. (2010), but the treatment of the stratospheric vertical profile has been improved. Section 2 briefly describes the measurements by CONTRAIL, NOAA, and NIES. Section 3 presents details of the calculation of $\mathrm{XCO}_{2}$ and estimation of its uncertainty. In Sect. 4, the results of the calculation of $\mathrm{XCO}_{2}$ temporal behavior are presented and their uncertainties are discussed.

\section{Observations}

Aircraft measurements obtained by CONTRAIL, NOAA, and NIES between 2007 and 2009 were used in this study. Details of each project have been reported elsewhere (Machida et al., 2001, 2008; Tans et al., 1996; ESRL/GMD CCGG Aircraft Program, 2011) and are only described briefly here. The locations of the CONTRAIL, NOAA, and NIES observations are shown in Fig. 1, and they are listed along with their three-letter site codes in Table 1.

The CONTRAIL project takes advantage of the numerous flights made by commercial airlines worldwide to acquire frequent measurements of $\mathrm{CO}_{2}$ at a relatively large number of sites. Automatic air sampling equipment for discrete sampling and continuous $\mathrm{CO}_{2}$ measuring equipment (CME) for in situ observations are installed on board aircraft operated by

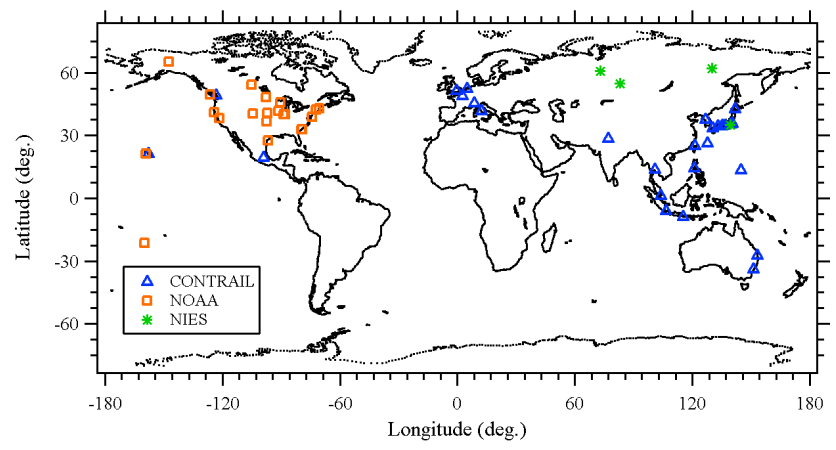

Fig. 1. Observation sites used in this study. Open triangles, open squares, and asterisks indicate CONTRAIL, NOAA, and NIES sites, respectively.

Japan Airlines. $\mathrm{XCO}_{2}$ is calculated from the data obtained by CME upon departure from and arrival at 28 different airports. These profiles differ from those obtained by the NOAA and NIES aircraft because the commercial aircraft move horizontally over a few hundred kilometers during their takeoff and landing. The data are typically collected at altitudes between a few kilometers and $10 \mathrm{~km}$ (Machida et al., 2008). Measurements are not carried out at regular time intervals at all locations. For example, there were 10 flights in May 2007 and only 2 flights in April 2007 at Schiphol Airport (AMS, Amsterdam, the Netherlands). The CME observations are calibrated on board the airplane with standard gases based on NIES $09 \mathrm{CO}_{2}$ scale, which is close to World Meteorological Organization (WMO) standards (Machida et al., 2011) at 10 min intervals during ascending and descending and at 40 min intervals during cruising. The uncertainty of the CME observations is estimated to be about $0.2 \mathrm{ppm}$ (Machida et al., 2008).

The NOAA measurements are from an aircraft observation network of 21 sites operated by the Global Monitoring Division of the Earth System Research Laboratory (GMD/ESRL). Flask sampling observations are performed several times a month, and the reported uncertainty is $\sim 0.15 \mathrm{ppm}$. The typical altitude range is from a few hundred meters to 5-8 km above ground level (ESRL/GMD CCGG Aircraft Program, 2011; http://www.esrl.noaa.gov/ gmd/ccgg/aircraft/index.html).

The measurements by NIES are made by flask sampling at three sites in Russia and one site in Japan. Sampling frequency is once or twice a month. Typical observing altitudes are $0.5-7 \mathrm{~km}$. The uncertainty is estimated to be $0.2 \mathrm{ppm}$, which takes into account the scale difference between standard gases (Machida et al., 2001).

\section{Method}

The calculation method used in this study is basically equivalent to that used by Araki et al. (2010) in their analysis, with 
the following modifications, mainly to make the method applicable to places anywhere in the world.

The vertical profiles of the $\mathrm{CO}_{2}$ mixing ratios in dry air are calculated from aircraft measurements made over a limited altitudinal range. Therefore, to calculate $\mathrm{XCO}_{2}$, additional information is needed: (1) supplemental vertical profiles of $\mathrm{CO}_{2}$ in the altitude range where observation data are not available, and (2) vertical profiles of the dry air number density above the sites. In this study, similar to Araki et al. (2010), these two types of profiles $\left(\mathrm{CO}_{2}\right.$ mixing ratio and the dry air number density) were prepared from ground level to $85 \mathrm{~km}$ above the ground.

To construct stratospheric profiles, Araki et al. (2010) used an empirical model of $\mathrm{CO}_{2}$ profiles at mid-latitudes in the Northern Hemisphere. In this model, the concentration is assumed to be constant above $20 \mathrm{~km}$ and values between the tropopause and $20 \mathrm{~km}$ are obtained by linear interpolation. In this study, profiles derived from the modeled "age of air" were used to calculate $\mathrm{XCO}_{2}$ at various latitudes. The age of air was obtained from simulations by the atmospheric general circulation model-based chemistry-transport model (ACTM) of the Center for Climate System Research/NIES/Frontier Research Center for Global Change (CCSR/NIES/FRCGC) (Patra et al., 2009). Before deriving vertical $\mathrm{CO}_{2}$ concentrations, we attempted to evaluate and correct the modeled age of air by observations. Although several gaseous species such as hydrogen fluoride (HF) and nitrous oxide $\left(\mathrm{N}_{2} \mathrm{O}\right)$ are available for tracers of motion (Loewenstein et al., 1989; Russell III et al., 1996), here we utilized sulfur hexafluoride $\left(\mathrm{SF}_{6}\right)$, which is one of the inert tracers most widely used to derive mean age (Stiller et al., 2012). The modeled age of air was compared with ages estimated by using several vertical profiles of sulfur hexafluoride $\left(\mathrm{SF}_{6}\right)$ in the upper troposphere and stratosphere in the latitude range of $17-70^{\circ} \mathrm{N}$, based on measurements made by balloon-borne instruments (Harnisch et al., 1996; Patra et al., 1997), to obtain correction factors at each profile location. The correction factors at each profile location were then interpolated and applied to all model grid cells between the equator and the North Pole. The mirror image was used for the Southern Hemisphere under the assumption that the age of air in the stratosphere is determined by vertical mixing at the equator (e.g., Andrews et al., 2001; Austin and Li, 2006). The ages were converted to $\mathrm{CO}_{2}$ mixing ratios by assuming that the tropospheric concentration (corresponding to 0 -yr-old mixing ratio) in 2006 was $381.2 \mathrm{ppm}$ and that the annual increasing trend was $1.9 \mathrm{ppm} \mathrm{yr}^{-1}$ at every site (WMO, 2006). This study estimated the mean age to be about 5-6 yr in the mid-latitude stratosphere $(24-50 \mathrm{~km})$. This result is consistent with the findings of other recent studies on the age of stratospheric air (e.g., Ishidoya et al., 2008; Engel et al., 2009). Zhu et al. (2000) showed that the mean age of air is about $6.5 \mathrm{yr}$, even at $80 \mathrm{~km}$, by using a globally balanced two-dimensional middle atmosphere model. The amount of $\mathrm{CO}_{2}$ above $50 \mathrm{~km}$ is so small that assumptions about the profile above $50 \mathrm{~km}$ do

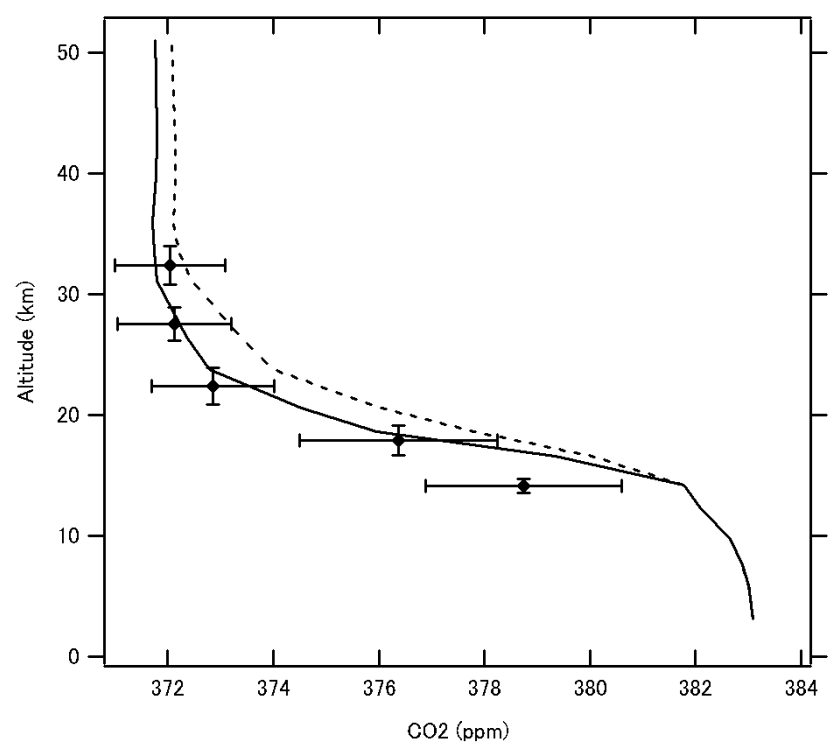

Fig. 2. Calculated $\mathrm{CO}_{2}$ profile at $40.5^{\circ} \mathrm{N}$ latitude from the modeled "age of air" (lines) and the observed profile (symbols) at Sanriku, Japan $\left(39.2^{\circ} \mathrm{N}\right)$ in January 2007. The dashed line shows the ACTM modeled profile uncorrected by the observed $\mathrm{SF}_{6}$ age of air, and the solid line shows the profile after normalization. Error bars of the observed data show the standard deviations of the mean.

not affect the results within the uncertainties. Therefore, the modeled profile was used up to $50 \mathrm{~km}$, and above $50 \mathrm{~km}$ the mixing ratio was assumed to be constant at the $50 \mathrm{~km}$ value. The $\mathrm{CO}_{2}$ profiles derived from the age of air have been compared with measurements of $\mathrm{CO}_{2}$ made by balloon-borne instruments over Japan from 1987 to 2007 at Sanriku (39.1 ${ }^{\circ}$ N, $141.8^{\circ}$ E) (Nakazawa et al., 1995). These data show an increasing trend of $1.52 \mathrm{ppm} \mathrm{yr}^{-1}$, so all data were normalized to 1 January 2007 using this value. The trend obtained at Sanriku differs from the world-average trend of $1.9 \mathrm{ppm} \mathrm{yr}^{-1}$ in the 2000s because it was determined by data collected over a different period (1996-2005). The normalized data were averaged within each altitude range: $15-20,20-25,25-30$, and above $30 \mathrm{~km}$. The uncorrected model clearly underestimated the age of air at most heights, particularly in the lower stratosphere (Fig. 2). When the $\mathrm{SF}_{6}$-corrected model ages were used, the age-based $\mathrm{CO}_{2}$ reconstruction successfully reproduced the observed rate of decrease for $\mathrm{CO}_{2}$ with increasing altitude in the stratosphere within a deviation of about $1.3 \mathrm{ppm}$ (root mean square). In this study, monthly averaged ACTM profiles were used after interpolating to the site location.

When the top measurement height was below the tropopause, the concentration measured at the highest altitude was assumed to be maintained up to the tropopause. The local tropopause height was obtained from the US National Centers for Environmental Prediction (NCEP) Global Forecast System (GFS), a global spectral numerical model based on primitive dynamical equations that includes a suite 
Table 1. Locations of the sites where aircraft measurements were made.

\begin{tabular}{|c|c|c|c|}
\hline \multicolumn{4}{|c|}{ (a) CONTRAIL } \\
\hline CODE & Latitude $\left({ }^{\circ} \mathrm{N}\right)$ & Longitude $\left({ }^{\circ} \mathrm{E}\right)$ & \\
\hline AMS & 52.3 & 4.8 & Schiphol Airport, the Netherlands \\
\hline LHR & 51.5 & -0.5 & Heathrow Airport, UK \\
\hline YVR & 49.2 & -123.2 & Vancouver International Airport, Canada \\
\hline CDG & 49.0 & 2.5 & Charles de Gaulle International Airport, France \\
\hline MXP & 45.6 & 8.7 & Milan Malpensa International Airport, Italy \\
\hline CTS & 42.8 & 141.7 & New Chitose Airport, Japan \\
\hline FCO & 41.8 & 12.3 & Fiumicino Airport, Italy \\
\hline $\mathrm{ICN}$ & 37.5 & 126.5 & Incheon International Airport, South Korea \\
\hline NRT & 35.8 & 140.4 & Narita International Airport, Japan \\
\hline HND & 35.6 & 139.8 & Tokyo International Airport, Japan \\
\hline NGO & 34.9 & 136.8 & Chubu Centrair International Airport, Japan \\
\hline ITM & 34.8 & 135.4 & Osaka International Airport, Japan \\
\hline HIJ & 34.4 & 132.9 & Hiroshima Airport, Japan \\
\hline KIX & 34.4 & 135.2 & Kansai International Airport, Japan \\
\hline FUK & 33.6 & 130.5 & Fukuoka Airport, Japan \\
\hline DEL & 28.6 & 77.1 & Indira Gandhi International Airport, India \\
\hline OKA & 26.2 & 127.6 & Naha Airport, Japan \\
\hline TPE & 25.1 & 121.2 & Taiwan Taoyuan International Airport, Taiwan \\
\hline HNL & 21.3 & -157.9 & Honolulu International Airport, USA \\
\hline MEX & 19.4 & -99.1 & Mexico City International Airport, Mexico \\
\hline MNL & 14.5 & 121.0 & Ninoy Aquino International Airport, Philippines \\
\hline BKK & 13.7 & 100.7 & Suvarnabhumi International Airport, Thailand \\
\hline GUM & 13.5 & 144.8 & Guam International Airport, USA \\
\hline SIN & 1.4 & 104.0 & Singapore Changi International Airport, Singapore \\
\hline CGK & -6.1 & 106.7 & Jakarta International Soekarno-Hatta Airport, Indonesia \\
\hline DPS & -8.7 & 115.2 & Ngurah Rai Airport, Indonesia \\
\hline $\mathrm{BNE}$ & -27.4 & 153.1 & Brisbane Airport, Australia \\
\hline SYD & -33.9 & 151.2 & Kingsford Smith Airport, Australia \\
\hline
\end{tabular}

(b) NOAA

\begin{tabular}{lrrl}
\hline CODE & Latitude $\left({ }^{\circ} \mathrm{N}\right)$ & Longitude $\left({ }^{\circ} \mathrm{E}\right)$ & \\
\hline AAO & 40.1 & -88.6 & Airborne Aerosol Observing, Illinois \\
BNE & 40.8 & -97.2 & Beaver Crossing, Nebraska \\
BRM & 54.3 & -105.0 & Berms, Saskatchewan \\
CAR & 40.4 & -104.3 & Briggsdale, Colorado \\
CMA & 38.8 & -74.3 & Cape May, New Jersey \\
DND & 48.4 & -97.8 & Dahlen, North Dakota \\
ESP & 49.6 & -126.4 & Estevan Point, British Columbia \\
HAA & 21.2 & -159.0 & Molokai Island, Hawaii \\
HFM & 42.5 & -72.2 & Harvard Forest, Massachusetts \\
HIL & 40.1 & -87.9 & Homer, Illinois \\
LEF & 45.9 & -90.3 & Park Falls, Wisconsin \\
NHA & 43.0 & -70.6 & Worcester, Massachusetts \\
PFA & 65.1 & -147.3 & Poker Flat, Alaska \\
RTA & -21.3 & -159.8 & Rarotonga, Cook Islands \\
SCA & 32.8 & -79.6 & Charleston, South Carolina \\
SGP & 36.8 & -97.5 & Southern Great Plains, Oklahoma \\
TGC & -96.9 & Sinton, Texas \\
THD & 27.7 & -124.2 & Trinidad Head, California \\
VAA & 41.1 & -79.4 & Cartersville, Georgia \\
WBI & 32.9 & -91.4 & West Branch, Iowa \\
WGC & 41.7 & & \\
\hline
\end{tabular}

(c) NIES

\begin{tabular}{lrrl}
\hline CODE & Latitude $\left({ }^{\circ} \mathrm{N}\right)$ & Longitude $\left({ }^{\circ} \mathrm{E}\right)$ & \\
\hline SGM & 35.1 & 139.3 & Sagami Bay, Japan \\
YAK & 62 & 130 & Yakutsk, Russia \\
NOV & 83 & Novosibirsk, Russia \\
SUR & 55 & 73 & Surgut, Russia \\
\hline
\end{tabular}



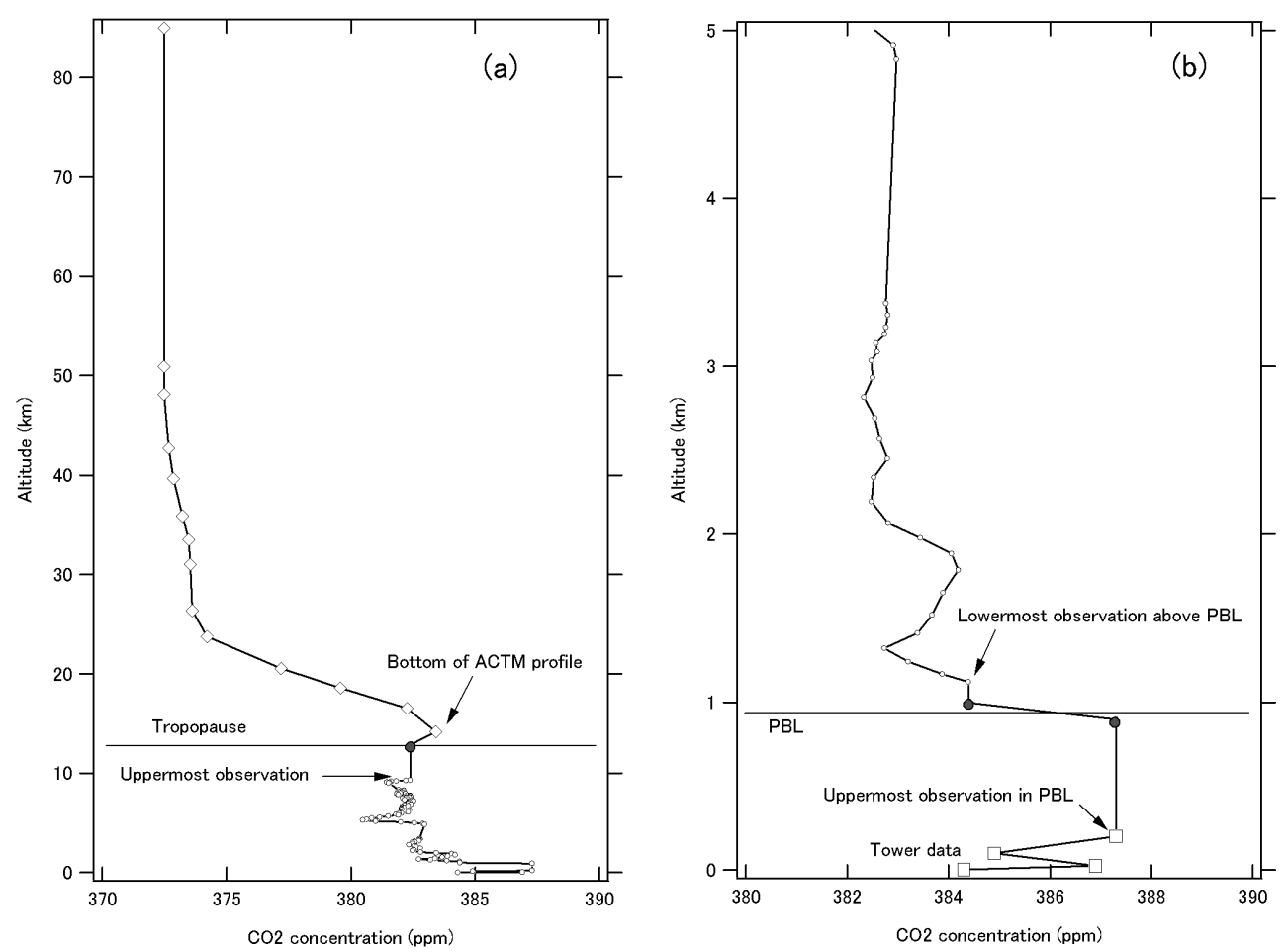

Fig. 3. Schematic example of a vertical $\mathrm{CO}_{2}$ profile: (a) the profile from the ground to $85 \mathrm{~km}$; (b) an expanded view of the profile between the ground and $5 \mathrm{~km}$. Open circles, squares, and diamonds show data observed by aircraft, data observed by towers, and the ACTM profile, respectively. Closed circles show the assumed value at the tropopause and the top of the PBL.

of parameterizations for atmospheric physics (Sela, 1980; Kalnay et al., 1990). The model is under constant development and evaluation (e.g., Yang et al., 2006).

To extrapolate profiles to the surface, tower data obtained at the Meteorological Research Institute (Tsukuba, $36.1^{\circ} \mathrm{N}$, $140.1^{\circ} \mathrm{E}$ ), the LEF, WBI, and WGC towers were used for aircraft measurements obtained over Narita Airport (Japan, NRT), Park Falls (Wisconsin, LEF), West Branch (Iowa, WBI) and Walnut Grove (California, WGC), respectively (Inoue and Matsueda, 1996; Andrews et al., 2011). Tower data for NOAA sites were acquired from the NOAA website (GMD Data Archive).

The concentration at the lowermost observation above the planetary boundary layer (PBL) was assumed to hold from that point to the top of the PBL. When there were observed data within the PBL, the concentration at the highest observation height within the PBL was extended to the PBL top, and that at the lowest observation height was extended to ground level. When there were no observation data within the PBL, the concentration of the lowermost observation above the PBL was assumed to hold to ground level. Local PBL heights for each site were obtained from NCEP GFS.

Figure 3 shows a schematic example of a profile constructed with these assumptions. Discontinuities between the observed profiles and ACTM stratospheric profiles were at most a few ppm (mean $\sim 1 \mathrm{ppm}$, standard deviation $\sim 1 \mathrm{ppm}$ ).
No correction was applied to resolve this discontinuity, but it is considered to be a source of uncertainty in the assumed profile, as discussed in Sect. 4.

The profiles of dry air number density were calculated by using the data sets of monthly mean climatological temperature and pressure of the Committee on Space Research (COSPAR) International Reference Atmosphere (CIRA)86 (e.g., Fleming et al., 1988, 1990), which are given at $5^{\circ}$ latitude intervals between $80^{\circ} \mathrm{N}$ and $80^{\circ} \mathrm{S}$ for altitudes of 0 to $120 \mathrm{~km}$. Values at each observation site were obtained by linear interpolation of CIRA- 86 data between two $5^{\circ}$ grid points. Monthly mean values were adopted without interpolation in time.

$\mathrm{XCO}_{2}$ was calculated by numerical integration of $\mathrm{CO}_{2}$ dry mole fractions weighted by the dry air density within $100 \mathrm{~m}$ layers from the ground up to $85 \mathrm{~km}$. It was assumed that the atmosphere was well mixed within each layer. Column abundance above $85 \mathrm{~km}$ was roughly estimated to be less than $0.01 \%$, which is small enough to be neglected in this study. If the $\mathrm{CO}_{2}$ mixing ratio (mole $\mathrm{CO}_{2} / \mathrm{mole}$ air) and dry air number density in the $i$-th layer are $n(i)$ and $N(i)$, respectively, $\mathrm{XCO}_{2}$ can be represented as

$$
\mathrm{XCO}_{2}=\sum_{\text {surface }}^{85 \mathrm{~km}} n(i) \times N(i) / N,
$$


where $N$ is the total column abundance of dry air, $N(i)$ is calculated by logarithmic interpolation of the vertical profile of CIRA-86 data with a vertical resolution of $2 \mathrm{~km}$, and $n(i)$ is calculated by linear interpolation between two neighboring observed or constructed data points. Araki et al. (2010) used only clear sky data for their analysis, whereas no screening by the weather conditions was done in this study.

The uncertainty of the $\mathrm{XCO}_{2}$ calculation caused by the profile assumptions was estimated for each flight. In this study, the focus is on the upper limit of the uncertainty, because that value is most important for the validation of satellite observations. Because $\mathrm{XCO}_{2}$ is the weighted mean of $\mathrm{CO}_{2}$ concentrations calculated by the dry air abundance in each layer, its uncertainty was determined by the assumed uncertainties of the partial $\mathrm{XCO}_{2}$ values and their weights. In this study, the uncertainty was defined as the standard deviation. We did not take into account the uncertainty of the dry air number density $N(i)$ (i.e., no variance) in this study because the $\mathrm{XCO}_{2}$ values calculated by using the CIRA-86 number densities agreed with rawinsonde values obtained over Tsukuba within $0.1 \mathrm{ppm}$ (Araki et al., 2010). The profiles were divided into four domains, within each of which the uncertainty of the data was treated as uniform: domain I, inside the PBL; domain II, region above the PBL with observed data; domain III, troposphere above the PBL without observed data; and domain IV, stratosphere without observed data. The uncertainty of total $\mathrm{XCO}_{2}$ is represented as follows:

$$
\text { uncertainty }=\frac{\sqrt{\sum_{j} N(j)^{2} \times \sigma(j)^{2}}}{N}(j=\mathrm{I}, \mathrm{II}, \mathrm{III}, \mathrm{IV}),
$$

where $\sigma(j)$ and $N(j)$ are the assumed uncertainty of partial $\mathrm{XCO}_{2}$ and the partial dry air number density in the $j$ th domain, respectively, and $N$ is the total sum of $N(j)$. It is difficult to determine the $\sigma(j)$ for each site from variance of the observed data because the amount of data is not enough for some sites. Therefore, we assumed the maximal $\sigma(j)$ common for all sites based on analysis of the observed data, which will be discussed in Sect. 4. $\sigma(\mathrm{I})$ was assumed to be $15 \mathrm{ppm}$ for flights with no data in the PBL or $2.89 \mathrm{ppm}$ (corresponding to a uniform distribution within $\pm 5 \mathrm{ppm}$ ) for flights with data in the PBL. $\sigma(\mathrm{II})$ was assumed to be $0.4 \mathrm{ppm}$, and $\sigma(\mathrm{III})$ and $\sigma(\mathrm{IV})$ were assumed to be $1.73 \mathrm{ppm}$ (corresponding to a uniform distribution within $\pm 3 \mathrm{ppm}$ ) (Table 2). The total uncertainty was determined from the height of the tropopause and the PBL, the uppermost and lowermost observation altitudes, the partial dry air abundances $N(j)$, and the uncertainties of partial $\mathrm{XCO}_{2} \sigma(j)$. The values of $\sigma(j)$ are critical for the estimation of total uncertainty, and their validity is discussed in Sect. 4.
Table 2. The assumed standard deviations of partial $\mathrm{XCO}_{2}$ in each domain.

\begin{tabular}{ll}
\hline Domain & $\begin{array}{l}\text { Standard } \\
\text { deviation } \\
(\mathrm{ppm})\end{array}$ \\
\hline I (No observed data in PBL) & 15 \\
I (With observed data in PBL) & 2.89 \\
II & 0.4 \\
III & 1.73 \\
IV & 1.73 \\
\hline
\end{tabular}

\section{Results and discussion}

Figure 4 shows the calculated $\mathrm{XCO}_{2}$ values and their uncertainties derived from the profile assumptions between 2007 and 2009 at the following 7 typical sites: NRT, NGO, CGK, BNE (NOAA), RTA, SGP and SUR. Results for all 53 sites are shown in the Supplement (Figs. S1, S2 and S3). As a visual guide, the following function was fitted to the $\mathrm{XCO}_{2}$ data:

$\mathrm{XCO}_{2}(t)=$

$a_{1}+a_{2} \times t+a_{3} \times \cos \left(2 \pi \frac{t-a_{4}}{365.25}\right)+a_{5} \times \cos \left(4 \pi \frac{t-a_{6}}{365.25}\right)$

where $a_{1}$ is the intercept at the zero time point ( 1 January 2007) without sinusoidal variations, $a_{2}$ represents the yearly trend of $\mathrm{XCO}_{2}, a_{3}$ and $a_{5}$ are the amplitudes of sinusoidal variations with a period of one year and a half year, respectively, and $a_{4}$ and $a_{6}$ are the phases of each sinusoidal variation. Annual sinusoidal variations and their latitudinal dependence are clearly seen. The amplitude of the seasonal cycle decreases from about $10 \mathrm{ppm}$ at high latitudes in the Northern Hemisphere to $2 \mathrm{ppm}$ or less in the tropics and the Southern Hemisphere. Compared with $\mathrm{XCO}_{2}$ at NRT in 2007, calculated by Araki et al. (2010), the temporal behavior of $\mathrm{XCO}_{2}$ is typically the same within our uncertainties.

The uncertainty estimation can be validated by comparing the partial $\mathrm{XCO}_{2}$ value calculated from the observed profile with the fitted profile for each domain. For domain I (PBL), the data sets containing observed data in the PBL were chosen and the $\mathrm{CO}_{2}$ concentrations at $5 \mathrm{~km}$ and $200 \mathrm{~m}$ were compared with the partial $\mathrm{XCO}_{2}$ in the PBL. The concentration at $5 \mathrm{~km}$ corresponds to the partial $\mathrm{XCO}_{2}$ assumed when a profile has no observed data in the PBL. The concentration at $200 \mathrm{~m}$ corresponds to the partial $\mathrm{XCO}_{2}$ assumed when a profile has only one observed datum in the PBL. For this analysis, sites that had sufficient observations in the PBL to evaluate the "true" partial $\mathrm{XCO}_{2}$ in the PBL were chosen. Therefore, sites with tower data were used for this analysis. The root mean square (RMS) of the deviation of the assumed partial $\mathrm{XCO}_{2}$ from the observed partial $\mathrm{XCO}_{2}$ was calculated. These comparisons show that the RMS in domain I was less than 3 ppm for flights with PBL data observations, and it was 
CONTRAIL
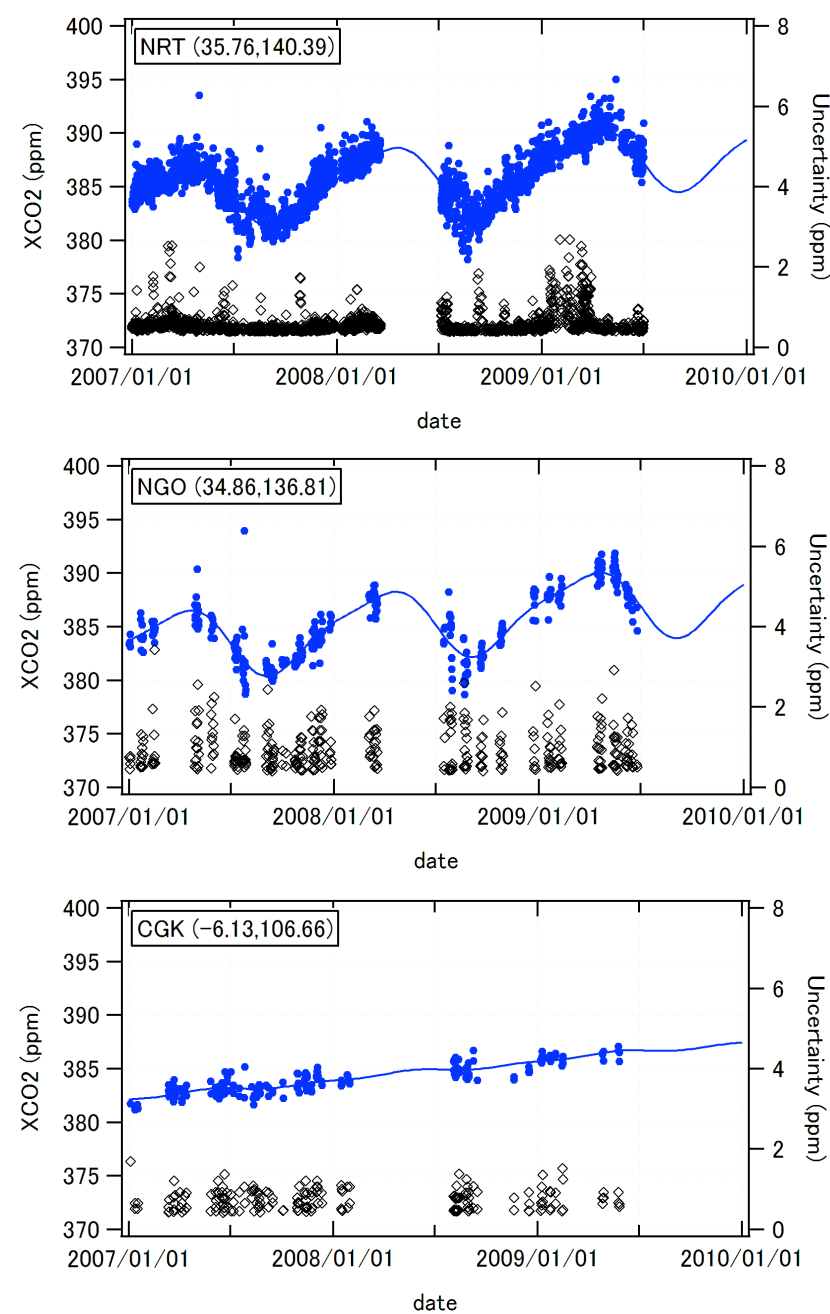

NOAA
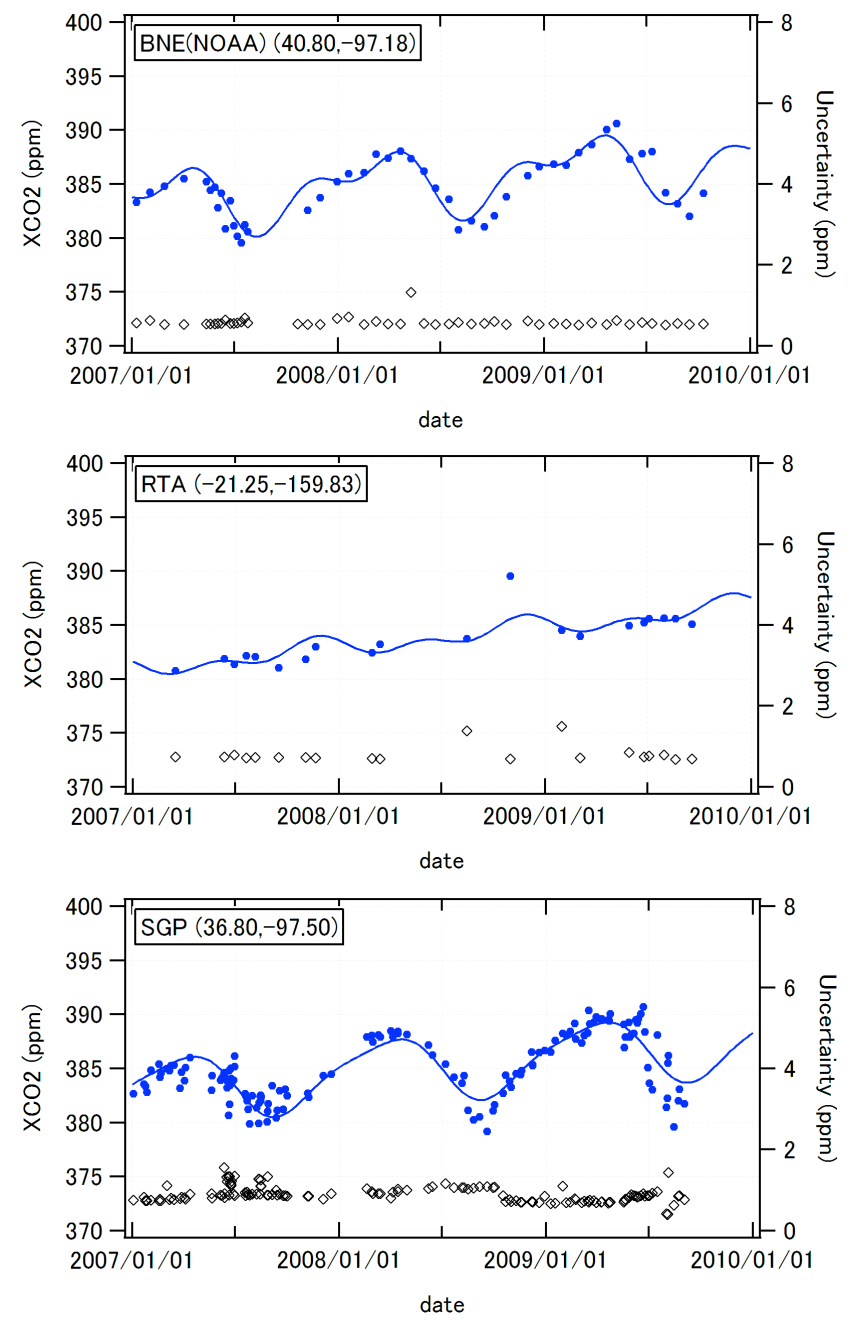

NIES

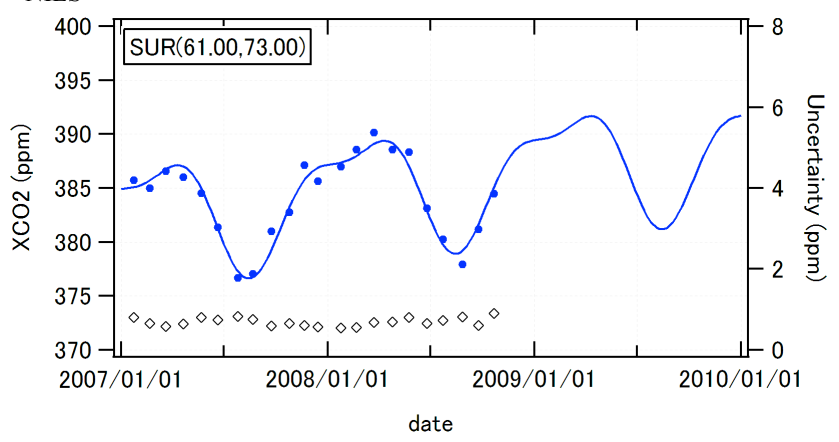

Fig. 4. Calculated $\mathrm{XCO}_{2}$ values and their estimated uncertainties at NRT, NGO, CGK, BNE (NOAA), RTA, SGP and SUR. The site code (Table 1) and its latitude and longitude are shown at the upper left corner of each panel. Blue filled circles show $\mathrm{XCO}_{2}$ (left axis), and black open rhomboids show their uncertainties (right axis). Blue solid lines show curves fitted to the temporal behavior of $\mathrm{XCO}_{2}$ as a visual guide (only for sites where the number of data was sufficient).

at most $15 \mathrm{ppm}$ for flights without PBL data. These values agree with our assumptions about partial uncertainties.

For domain II (observation region above the PBL), the reported standard deviation of the measurements was typically
$0.2 \mathrm{ppm}$. Here, we assumed that $\sigma$ (II) was $0.4 \mathrm{ppm}$, which corresponds to $2 \sigma$.

For domain III (troposphere without observations above the PBL), the data sets containing observed data from the 
top of the PBL to the tropopause were chosen to evaluate the "true" partial $\mathrm{XCO}_{2}$ of the whole troposphere above the PBL; the $\mathrm{CO}_{2}$ concentrations at $5 \mathrm{~km}$ were compared with the partial $\mathrm{XCO}_{2}$ calculated from the observed profile. Here, the $\mathrm{CO}_{2}$ concentration at $5 \mathrm{~km}$ was assumed to be the partial $\mathrm{XCO}_{2}$ when only one observation was available in the troposphere above the PBL. This analysis can determine the upper limit of uncertainties in domain III because nearly all data sets include many observations in the troposphere above the PBL. The comparison showed that the uncertainty in domain III was at most $1.5 \mathrm{ppm}$, so the assumption of $1.73 \mathrm{ppm}$ (the standard deviation corresponding to a uniform distribution within $\pm 3 \mathrm{ppm}$ ) is a good approximation, though slightly high.

For domain IV (stratosphere without observation data), it is difficult to obtain an "observed" partial $\mathrm{XCO}_{2}$, so the difference between the uppermost observed data in the stratosphere and the nearest corrected age of air estimate from the ACTM was used. The standard deviations of the errors were from 1.5 to $2.0 \mathrm{ppm}$, so the assumption of $1.73 \mathrm{ppm}$ appears reasonable.

The total uncertainties calculated (Eq. 2) from all of the profile assumptions were at most $2 \mathrm{ppm}$ and typically between 0.5 and $1.0 \mathrm{ppm}$. The uncertainty values strongly depended on whether observations from the PBL were available. They were large at CONTRAIL sites where the lowermost observation altitudes were relatively high, often above the top of the PBL. At NRT, the use of Tsukuba tower data (Meteorological Research Institute) reduced the uncertainty to less than $1 \mathrm{ppm}$. When tower data were not available, the uncertainty at NRT was large. The uncertainties at NOAA and NIES sites were basically uniform with values less than $1 \mathrm{ppm}$. At the NOAA sites with the largest uncertainties (AAO, LEF, SGP, and WGC), the uncertainties were nearly $1 \mathrm{ppm}$. At these sites, the uppermost observation altitude was typically $\sim 4000 \mathrm{~m}$, which is lower than at the other sites and caused the uncertainties to be larger. At PFA, the uncertainties were also large, in this case because the height of the lowermost observation was often above the top of the PBL. It is difficult to detect any seasonal behavior of the uncertainties at CONTRAIL sites, where the uppermost observation altitude was relatively high. For reference, frequency distributions of the estimated uncertainties at NRT, NGO, BNE (NOAA), SGP, and SUR are shown in Fig. 5.

Araki et al. (2010) estimated the uncertainties derived from the CIRA-86 dry air number density data and the NCEP tropopause height data by comparing their results obtained with NCEP and CIRA-86 data with those obtained by using rawinsonde measurement data instead. They estimated the uncertainty from the CIRA- 86 data to be $0.08 \mathrm{ppm}$, which is relatively insignificant compared with our estimated total uncertainties. They did not report the uncertainties from the NCEP tropopause heights, but they estimated the uncertainties from both the NCEP tropopause height and their assumptions about profiles near the surface to be $0.92 \mathrm{ppm}$ (Araki
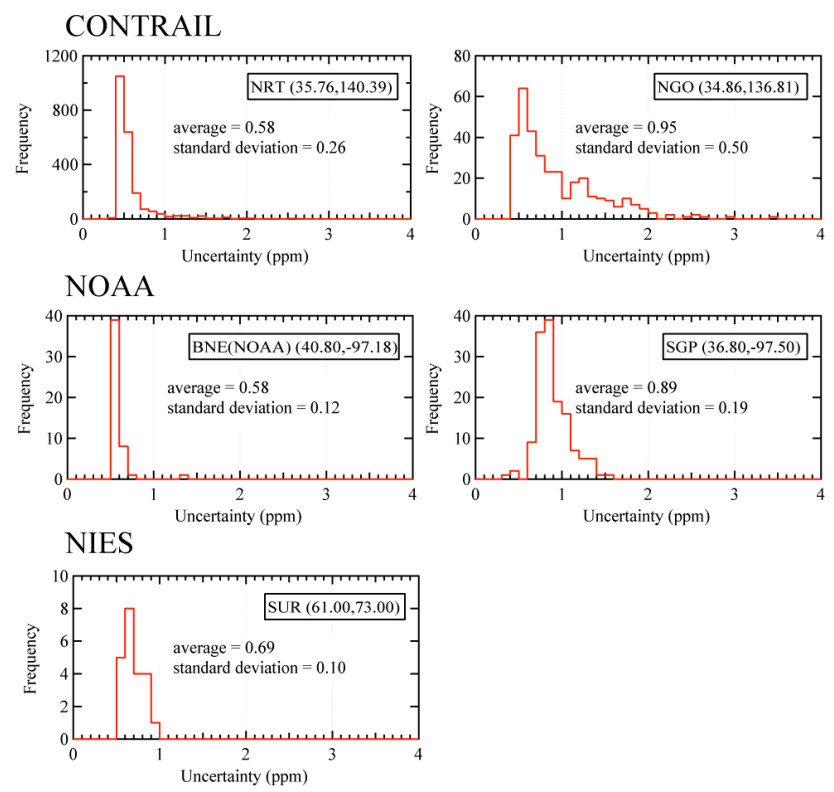

Fig. 5. Frequency distributions of the estimated uncertainties at five sites. The size of each frequency class is $0.1 \mathrm{ppm}$.

et al., 2010). Therefore, the uncertainties from the NCEP tropopause height were also small because the uncertainties from the profiles near the surface were dominant and can be treated as part of the uncertainties derived from the profile assumptions, as described above. In addition, we investigated the statistics of the PBL heights and the impact of the PBL heights on the $\mathrm{XCO}_{2}$ calculation. For instance, an average and one standard deviation of PBL heights at AMS are $816 \pm 434 \mathrm{~m}$. The maximum and minimum are $1902 \mathrm{~m}$ and $159 \mathrm{~m}$, respectively. Based on these results, the differences between " $\mathrm{XCO}_{2}$ where PBL heights are true values $\left(\mathrm{PBL}_{\text {true }}\right.$ $\left.\mathrm{XCO}_{2}\right)$ " and " $\mathrm{XCO}_{2}$ where they are assumed to be $1500 \mathrm{~m}$ $\left(\mathrm{PBL}_{1500} \mathrm{XCO}_{2}\right)$ or $200 \mathrm{~m}\left(\mathrm{PBL}_{200} \mathrm{XCO}_{2}\right)$ " are estimated at NRT, AMS, SYD, and HNL sites. At AMS, the differences between $\mathrm{PBL}_{\text {true }} \mathrm{XCO}_{2}$ and $\mathrm{PBL}_{1500} \mathrm{XCO}_{2}\left(\mathrm{PBL}_{\text {true }}\right.$ $\mathrm{XCO}_{2}$ minus $\mathrm{PBL}_{1500} \mathrm{XCO}_{2}$ ) are less than $\pm 0.21 \mathrm{ppm}$ at most, and average of the differences and one standard deviation are $0.00 \pm 0.03 \mathrm{ppm}$. On the other hand, the differences between $\mathrm{PBL}_{\text {true }} \mathrm{XCO}_{2}$ and $\mathrm{PBL}_{200} \mathrm{XCO}_{2}\left(\mathrm{PBL}_{\text {true }} \mathrm{XCO}_{2}\right.$ minus $\mathrm{PBL}_{200} \mathrm{XCO}_{2}$ ) at $\mathrm{AMS}$ are less than $\pm 0.20 \mathrm{ppm}$ at most and $0.00 \pm 0.03 \mathrm{ppm}$ on average. Also, we found that the impact of PBL heights on the aircraft-based $\mathrm{XCO}_{2}$ calculation is not large at other sites.

\section{Conclusions}

$\mathrm{XCO}_{2}$ at 53 sites in the world was calculated from aircraft measurement data obtained by CONTRAIL, NOAA, and NIES between 2007 and 2009 along with tower data obtained at the surface and the ACTM simulated age of air to estimate profiles in the stratosphere. The amplitudes of seasonal 
cycles decreased from north to south. The estimated upper limits of the uncertainties of $\mathrm{XCO}_{2}$ were typically less than $1 \mathrm{ppm}$, suggesting that this data set is suitable for evaluation of $\mathrm{XCO}_{2}$ estimates by satellites.

Recently, $\mathrm{XCO}_{2}$ has been derived from data obtained by satellites, such as GOSAT (Yokota et al., 2009), the Scanning Imaging Absorption Spectrometer for Atmospheric Chartography (SCIAMACHY; Bovensmann et al., 1999) on board ENVISAT, and the Atmospheric Infrared Sounder (AIRS; Crevoisier et al., 2004) on board NASA's Aqua platform. These satellite data are considered useful for decreasing the flux estimation errors in global atmospheric transport models and for investigating $\mathrm{CO}_{2}$ sources and the carbon cycle in more detail. However, it is necessary to validate these data for such scientific applications. The profile data of aircraft measurements cannot be directly compared with the columnaveraged data from satellites. In this work, we therefore propose a method for converting the profile data from aircraft to column-averaged data and for estimating the uncertainties of the calculated values. Our analysis suggests that the uncertainties are small enough for the aircraft data to be used for primary validation of satellite data. When comparing $\mathrm{XCO}_{2}$ derived from the satellite measurements such as GOSAT with the aircraft data, the column averaging kernels (CAKs) of satellite measurements should be taken into account. Although much attention needs to be paid to using this $\mathrm{XCO}_{2}$ data set since it is not calculated with consideration of CAKs, it is very useful within the scientific community. Therefore, we would like to provide the $\mathrm{XCO}_{2}$ data set without applying CAKs on request. Furthermore, it should be possible to extend the method to other species such as methane using tracer-tracer correlation method or climatology of satellite data.

\section{Supplementary material related to this article is available online at: http://www.atmos-chem-phys.net/13/ 5265/2013/acp-13-5265-2013-supplement.pdf.}

Acknowledgements. We acknowledge the many staff members of Japan Airlines, the JAL Foundation, and JAMCO Tokyo for supporting the CONTRAIL project. We also thank Takakiyo Nakazawa for providing the balloon-borne data. The NOAA/ESRL Tall Tower project relies heavily on partnerships with universities and other agencies. Individuals who have made significant contributions to the data set used in this study include Ankur Desai of the University of Wisconsin (LEF), Charles Stanier of the University of Iowa (WBI), and Marc Fischer of Lawrence Berkeley National Laboratory (WGC). This research was supported in part by the Environment Research and Technology Development Fund (A-1102) of the Ministry of the Environment, Japan.

Edited by: C. Gerbig

\section{References}

Andrews, A. E., Boering, K. A., Daube, B. C., Wofsy, S. C., Loewenstein, M., Jost, H., Podolske, J. R., Webster, C. R., Herman, R. L., Scott, D. C., Flesch, G. J., Moyer, E. J., Elkins, J. W., Dutton, G. S., Hurst, D . F., Moore, F. L., Ray, E. A., Romashkin, P. A., and Strahan, S. E.: Mean ages of stratospheric air derived from in situ observations of $\mathrm{CO}_{2}, \mathrm{CH}_{4}$, and $\mathrm{N}_{2} \mathrm{O}$, J. Geophys. Res., 106, 32295-32314, doi:10.1029/2001JD000465, 2001.

Andrews, A. E., Kofler J., Bakwin P. S., Zhao C., and Tans P.: Carbon dioxide and carbon monoxide dry air mole fractions from the NOAA ESRL tall tower network, 1992-2009, Version: 2011-0831, Path: ftp://ftp.cmdl.noaa.gov/ccg/towers/, 2011.

Araki, M., Morino, I., Machida, T., Sawa, Y., Matsueda, H., Ohyama, H., Yokota, T., and Uchino, O.: $\mathrm{CO}_{2}$ column-averaged volume mixing ratio derived over Tsukuba from measurements by commercial airlines, Atmos. Chem. Phys., 10, 7659-7667, doi:10.5194/acp-10-7659-2010, 2010.

Austin, J. and Li, F.: On the relationship between the strength of the Brewer-Dobson circulation and the age of stratospheric air, Geophys. Res. Lett., 33, L17807, doi:10.1029/2006GL026867, 2006.

Bovensmann, H., Burrows, J. P., Buchwitz, M., Frerick, J., Noël, S., Rozanov, V. V., Chance, K. V., and Goede, A. P. H.: SCIAMACHY: Mission Objectives and Measurement Modes, J. Atmos. Sci., 56, 127-150, 1999.

COSPAR (Committee on Space Research): The COSPAR International Reference Atmosphere (CIRA-86), British Atmospheric Data Center, http://badc.nerc.ac.uk/view/badc.nerc.ac. uk__ATOM_dataent_CIRA (last access: 21 May 2013), 2013.

Crevoisier, C., Heilliette, S., Chédin, A., Serrar, S., Armante, R., and Scott, N. A.: Midtropospheric $\mathrm{CO}_{2}$ concentration retrieval from AIRS observations in the tropics, Geophys. Res. Lett., 31, L17106, doi:10.1029/2004GL020141, 2004.

Engel, A., Möbius, T., Bönisch, H., Schmidt, U., Heinz, R., Levin, I., Atlas, E., Aoki, S., Nakazawa, T., Sugawara, S., Moore, F., Hurst, D., Elkins, J., Schauffler, S., Andrews, A., and Boering, K.: Age of stratospheric air unchanged within uncertainties over the past 30 years, Nature Geosci., 2, 28-31, doi:10.1038/ngeo388, 2009.

Fleming, E. L., Chandra, S., Shoeberl, M. R., and Barnett, J. J.: Monthly mean global climatology of temperature, wind, geopotential height and pressure for $0-120 \mathrm{~km}$, National Aeronautics and Space Administration, Technical Memorandum 100697 , Washington, DC, USA, 1988.

Fleming, E. L., Chandra, S., Barnett, J. J., and Corney, M.: Zonal mean temperature, pressure, zonal wind and geopotential height as functions of latitude, Adv. Space Res., 10, 11-59, doi:10.1016/0273-1177(90)90386-E, 1990.

GMD Data Archive: Global Monitoring Division, Earth System Research Laboratory, NOAA, http://www.esrl.noaa.gov/gmd/dv/ ftpdata.html (last access: 21 May 2013), 2013.

Harnisch, J., Borchers, R., Fabian, P., and Maiss, M.: Tropospheric trends for $\mathrm{CF}_{4}$ and $\mathrm{C}_{2} \mathrm{~F}_{6}$ since 1982 derived from $\mathrm{SF}_{6}$ dated stratospheric air, Geophys. Res. Lett., 23, 1099-1102, doi:10.1029/96GL01198, 1996.

Inoue, H. Y. and Matsueda, H.: Variations in atmospheric $\mathrm{CO}_{2}$ at the Meteorological Research Institute, Tsukuba, Japan, J. Atoms. Chem., 23, 137-161, 1996. 
Ishidoya, S., Sugawara, S., Morimoto, S., Aoki S., and Nakazawa T.: Gravitational separation of major atmospheric components of nitrogen and oxygen in the stratosphere, Geophys. Res. Lett., 35, L03811, doi:10.1029/2007GL030456, 2008.

Kalnay, E., Kanamitsu, M., and Baker, W. E.: Global numerical weather prediction at the National Meteorological Center, B. Am. Meteor. Soc., 71, 1410-1428, 1990.

Kuze, A., Suto, H., Nakajima, M., and Hamazaki, T.: Thermal and near infrared sensor for carbon observation Fourier-transform spectrometer on the Greenhouse Gases Observing Satellite for greenhouse gases monitoring, Appl. Optics, 48, 6716-6733 doi:10.1364/AO.48.006716, 2009.

Loewenstein, M., Podolske, J. R., Chan, K. R., and Strahan, S. E.: Nitrous oxide as a dynamical tracer in the 1987 Airborne Antarctic Ozone Experiment, J. Geophys. Res., 94, 11589-11598, doi:10.1029/JD094iD09p11589, 1989.

Machida, T., Nakazawa, T., Ishidoya, S., Maksyutov, S., Tohjima, Y., Takahashi, Y., Watai, T., Vinnichenko, N., Panchenko, M., Arshinov, M., Fedoseev, N., and Inoue, G.: Temporal and spatial variations of atmospheric $\mathrm{CO}_{2}$ mixing ratio over Siberia, Proceedings of The Sixth International $\mathrm{CO}_{2}$ Conference, Sendai, Japan, 1-5 October, 2001.

Machida, T., Matsueda, H., Sawa, Y., Nakagawa, Y., Hirotani, K., Kondo, N., Goto, K., Nakazawa, T., Ishikawa, K., and Ogawa, T.: Worldwide Measurements of Atmospheric $\mathrm{CO}_{2}$ and Other Trace Gas Species Using Commercial Airlines, J. Atmos. Oceanic. Technol., 25, 1744-1754, doi:10.1175/2008JTECHA1082.1, 2008.

Machida, T., Tohjima, Y., Katsumata, K., and Mukai, H.: A new $\mathrm{CO}_{2}$ calibration scale based on gravimetric one-step dilution cylinders in National Institute for Environmental Studies-NIES $09 \mathrm{CO}_{2}$ scale, GAW Report, 194, 114-119, 15th WMO/IAEA Meeting of Experts on Carbon Dioxide, Other Greenhouse Gases and Related Tracers Measurement Techniques, WMO/TD No. 1553, 2011.

Miller, C. E., Crisp, D., DeCola, P. L., Olsen, S. C., Randerson, J. T., Michalak, A. M., Alkhaled, A., Rayner, P., Jacob, D. J., Suntharalingam, P., Jones, D. B. A., Denning, A. S., Nicholls, M. E., Doney, S. C., Pawson, S., Boesch, H., Connor, B. J., Fung, I. Y., O'Brien, D., Salawitch, R. J., Sander, S. P., Sen, B., Tans, P., Toon, G. C., Wennberg, P. O., Wofsy, S. C., Yung, Y. L., and Law, R. M.: Precision requirements for space-based $\mathrm{XCO}_{2}$ data, J. Geophys. Res., 112, D10314, doi:10.1029/2006JD007659, 2007.

Morino, I., Uchino, O., Inoue, M., Yoshida, Y., Yokota, T., Wennberg, P. O., Toon, G. C., Wunch, D., Roehl, C. M., Notholt, J., Warneke, T., Messerschmidt, J., Griffith, D. W. T., Deutscher, N. M., Sherlock, V., Connor, B., Robinson, J., Sussmann, R., and Rettinger, M.: Preliminary validation of column-averaged volume mixing ratios of carbon dioxide and methane retrieved from GOSAT short-wavelength infrared spectra, Atmos. Meas. Tech., 4, 1061-1076, doi:10.5194/amt-4-1061-2011, 2011.

Nakazawa, T., Machida, T., Sugawara, S., Murayama, S., Morimoto, S., Hashida, G., Honda, H., and Itoh, T.: Measurements of the stratospheric carbon dioxide concentration over Japan using a balloon-borne cryogenic sampler, Geophys. Res. Lett., 22, 1229-1232, doi:10.1029/95GL01188, 1995.

NCEP: NOAA/National Weather Service, National Center for Environmental Prediction, NCEP Internet Services Team, available at: http://www.ncep.noaa.gov/ (last access: 21 May 2013), 2013.
NOAA/ESRL Carbon Cycle Greenhouse Gases Aircraft Program, available at: http://www.esrl.noaa.gov/gmd/ccgg/aircraft/index. html (last access: 21 May 2013), 2013.

Patra, P. K., Lal, S., Subbaraya, B. H., Jackman, C. H., and Rajaratnam, P.: Observed vertical profile of sulphur hexafluoride $\left(\mathrm{SF}_{6}\right)$ and its atmospheric applications, J. Geophys. Res., 102, 88558859, 1997.

Patra, P. K., Maksyutov, S., Sasano, Y., Nakajima, H., Inoue, G., and Nakazawa, T.: An evaluation of $\mathrm{CO}_{2}$ observations with Solar Occultation FTS for Inclined-Orbit Satellite sensor for surface source inversion, J. Geophys. Res., 108, 4759, doi:10.1029/2003JD003661, 2003.

Patra, P. K., Takigawa, M., Dutton, G. S., Uhse, K., Ishijima, K., Lintner, B. R., Miyazaki, K., and Elkins, J. W.: Transport mechanisms for synoptic, seasonal and interannual $\mathrm{SF}_{6}$ variations and "age" of air in troposphere, Atmos. Chem. Phys., 9, 1209-1225, doi:10.5194/acp-9-1209-2009, 2009.

Rayner, P. J., Law, R. M., O’Brien, D. M., Butler, T. M., and Dilley, A. C.: Global observations of the carbon budget 3. Initial assessment of the impact of satellite orbit, scan geometry, and cloud on measuring $\mathrm{CO}_{2}$ from space, J. Geophys. Res., 107, 4557, doi:10.1029/2001JD000618, 2002.

Russell III, J. M., Deaver, L. E., Luo, M., Cicerone, R. J., Park, J. H., Gordley, L. L., Toon, G. C., Gunson, M. R., Traub, W. A., Johnson, D. G., Jucks, K. W., Zander, R., and Nolt, I. G.: Validation of hydrogen fluoride measurements made by the Halogen Occultation Experiment from the UARS platform, J. Geophys. Res., 101, 10163-10174, doi:10.1029/95JD01705, 1996.

Schneising, O., Bergamaschi, P., Bovensmann, H., Buchwitz, M., Burrows, J. P., Deutscher, N. M., Griffith, D. W. T., Heymann, J., Macatangay, R., Messerschmidt, J., Notholt, J., Rettinger, M., Reuter, M., Sussmann, R., Velazco, V. A., Warneke, T., Wennberg, P. O., and Wunch, D.: Atmospheric greenhouse gases retrieved from SCIAMACHY: comparison to ground-based FTS measurements and model results, Atmos. Chem. Phys., 12, 1527-1540, doi:10.5194/acp-12-1527-2012, 2012.

Sela, J.: Spectral modeling at the National Meteorological Center, Mon. Wea. Rev., 108, 1279-1292, 1980.

Stiller, G. P., von Clarmann, T., Haenel, F., Funke, B., Glatthor, N., Grabowski, U., Kellmann, S., Kiefer, M., Linden, A., Lossow, S., and López-Puertas, M.: Observed temporal evolution of global mean age of stratospheric air for the 2002 to 2010 period, Atmos. Chem. Phys., 12, 3311-3331, doi:10.5194/acp-12-33112012, 2012.

Tans, P. P., Bakwin, P. S., Conway, T. J., Dissly, R. W., Dlugokencky, E. J., Geller, L. S., Guenther, D. W., Hurst, D. F., Kitzis, D. R.., Lang, P. M., Masarie, K. A., Miller, J. B., Novelli, P. C., Prostko-Bell, C., Ramonet, M., Thoning, K. W., Trolier, M., Waterman, L.S., Zhang, N., and Zhao, C.: Carbon Cycle (Group Report), Climate Monitoring and Diagnostics Laboratory, No. 23, Summary Report 1994-1995, Hoffman, D. J., Peterson, J. T., and Rosson, R. M., US Department of Commerce, Boulder, Colorado, 1996.

WDCGG: WMO Global Atmosphere Watch, World Data Centre for Greenhouse Gases, http://ds.data.jma.go.jp/gmd/wdcgg/ (last access: 10 October 2012), 2012.

WMO: WMO Greenhouse Gas Bulletin, No. 3, World Meteorological Organization, http://www.wmo.int/pages/prog/arep/gaw/ghg/ GHGbulletin.html, 2006. 
Wunch, D., Toon, G. C., Wennberg, P. O., Wofsy, S. C., Stephens, B. B., Fischer, M. L., Uchino, O., Abshire, J. B., Bernath, P., Biraud, S. C., Blavier, J.-F. L., Boone, C., Bowman, K. P., Browell, E. V., Campos, T., Connor, B. J., Daube, B. C., Deutscher, N. M., Diao, M., Elkins, J. W., Gerbig, C., Gottlieb, E., Griffith, D. W. T., Hurst, D. F., Jiménez, R., Keppel-Aleks, G., Kort, E. A., Macatangay, R., Machida, T., Matsueda, H., Moore, F., Morino, I., Park, S., Robinson, J., Roehl, C. M., Sawa, Y., Sherlock, V., Sweeney, C., Tanaka, T., and Zondlo, M. A.: Calibration of the Total Carbon Column Observing Network using aircraft profile data, Atmos. Meas. Tech., 3, 1351-1362, doi:10.5194/amt3-1351-2010, 2010.

Wunch, D., Toon, G. C., Blavier, J.-F. L., Washenfelder, R. A., Notholt, J., Connor, B. J., Griffith, D. W. T., Sherlock, V., and Wennberg, P. O.: The Total Carbon Column Observing Network, Philos. T. Roy. Soc. A, 369, 2087-2112, doi:10.1098/rsta.2010.0240, 2011a.

Wunch, D., Wennberg, P. O., Toon, G. C., Connor, B. J., Fisher, B., Osterman, G. B., Frankenberg, C., Mandrake, L., O'Dell, C., Ahonen, P., Biraud, S. C., Castano, R., Cressie, N., Crisp, D., Deutscher, N. M., Eldering, A., Fischer, M. L., Griffith, D. W. T., Gunson, M., Heikkinen, P., Keppel-Aleks, G., Kyrö, E., Lindenmaier, R., Macatangay, R., Mendonca, J., Messerschmidt, J., Miller, C. E., Morino, I., Notholt, J., Oyafuso, F. A., Rettinger, M., Robinson, J., Roehl, C. M., Salawitch, R. J., Sherlock, V., Strong, K., Sussmann, R., Tanaka, T., Thompson, D. R., Uchino, O., Warneke, T., and Wofsy, S. C.: A method for evaluating bias in global measurements of $\mathrm{CO}_{2}$ total columns from space, Atmos. Chem. Phys., 11, 12317-12337, doi:10.5194/acp11-12317-2011, $2011 b$.
Yang, F., Pan, H.-L., Krueger, S. K., Moorthi, S., and Lord, S. J.: Evaluation of the NCEP Global Forecast System at the ARM SGP site, Mon. Weather Rev., 134, 3668-3690, 2006.

Yokota, T., Yoshida, Y., Eguchi, N., Ota, Y., Tanaka, T., Watanabe, H., and Maksyutov, S.: Global Concentrations of $\mathrm{CO}_{2}$ and $\mathrm{CH}_{4}$ Retrieved from GOSAT: First Preliminary Results, SOLA, 5, 160-163, doi:10.2151/sola.2009-041, 2009.

Yoshida, Y., Ota, Y., Eguchi, N., Kikuchi, N., Nobuta, K., Tran, H., Morino, I., and Yokota, T.: Retrieval algorithm for $\mathrm{CO}_{2}$ and $\mathrm{CH}_{4}$ column abundances from short-wavelength infrared spectral observations by the Greenhouse gases observing satellite, Atmos. Meas. Tech., 4, 717-734, doi:10.5194/amt-4-717-2011, 2011.

Zhu, X., Yee, J.-H., and Strobel, D. F.: Middle atmosphere age of air in a globally balanced two-dimensional model, J. Geophys. Res., 105, 15201-15212, 2000. 